\title{
FragmentS OF AN EMPEROR'S RELIGIOUS POLICY: THE CASE OF HADRIAN* \\ FRAGMENTOS DE LA POLÍTICA RELIGIOSA \\ DE UN EMPERADOR: EL CASO DE ADRIANO
}

Greg WoolF

Institute of Classical Studies, University of London GREG.WOOLF@SAS.AC.UK

\begin{abstract}
Neither the concept of "imperial policy" nor of "religion" are easily applied to antiquity. Yet the activities of Roman emperors often did have consequences for religious activity, and their behaviour was not necessarily chaotic or random. Hadrian provides a good case for examining how religious activity was incorporated into ancient biography and historical writing, and how it was related to other fields of imperial conduct. A good deal is recorded about Hadrian's
\end{abstract}

\section{RESUMEN}

Ni el concepto "política imperial" ni el de "religión" son fácilmente aplicables a la Antigüedad. A pesar de ello, la labor de los emperadores romanos tuvo, frecuentemente, un notable impacto sobre la actividad religiosa, y su comportamiento no fue, necesariamente, caótico o aleatorio. Adriano proporciona un buen caso para examinar cómo la actividad religiosa del emperador fue incorporada a las biografías antiguas y a la narración histórica, y cómo estaba relacionada con

*This article has been researched with in the project Adriano y la integración de la diversidad regional. Una perspectiva histórica e historiográfica (HAR2015-65451-C2-1-P), 01/01/2016 - 31/12/2018 of the University Pablo de Olavide. 
conduct of religious offices, his building projects and his engagement with older tradition, Roman and foreign. The dossier of testimonia does reveals some consistencies in his behaviour but these seem to derive less from policy than from habits of thought and action. Many of his actions can be interpreted as conventional, even if sometimes performed on an unconventional scale. Hadrian certainly exercised agency, and he had particular dispositions as a ruler. But religious policy seems an anachronistic term to apply to his conduct. otros ámbitos de la acción imperial. Nos ha llegado mucha información sobre la actividad adrianea relativa a cargos religiosos, a sus proyectos edilicios y a su vinculación con la tradición anterior, romana y extranjera. El elenco de testimonia revela una cierta consistencia en su comportamiento, pero parece derivar menos de la política que de hábitos de pensamiento y acción. Muchas de sus acciones pueden ser interpretadas como convencionales, incluso si algunas veces se llevaron a cabo a una escala inusual. Ciertamente, Adriano ejerció su voluntad, y tuvo una disposición particular como gobernante. Pero el término "política religiosa" parece un anacronismo al aplicarlo sobre su conducta.
KeYWORDS

Hadrian, Religionspolitik, Roman Emperors, Jerusalem
Palabras Clave

Adriano, política religiosa, emperadores romanos, Jerusalén 
Sacra Romana diligentissime curavit, peregrina contempsit. Pontificis maximi officium peregit.

Roman rites he most carefully observed, foreign ones he despised. He always carried out the duties of the Pontifex Maximus.

Hist. Aug., Had. 22, 10 (trans. Birley)

There are excellent reasons to avoid the term Religious Policy when discussing the Roman Empire. The idea that emperors had policies in a modern sense was categorically rejected more than forty years ago. ${ }^{1}$ More recently the use of the term 'religion' in relation to antiquity has also been challenged. ${ }^{2}$ In a world without clearly defined and mutually exclusive religions or confessions, the technical term 'Religionspolitik' has little meaning, ${ }^{3}$ Hadrian was exceptional in many ways, including for the range of his cultural engagements and for his many interventions across the empire. ${ }^{4}$ Yet in this respect he was entirely typical. Hadrian had no Religious Policy.

Yet it would not be correct either to say that Hadrian had no impact on the religious life of the empire, nor were his interventions random and chaotic. Ancient writers present a broadly consistent picture of his actions, one that is largely confirmed when other evidence is considered. Indeed Hadrian's interactions with var-

1. Millar, 1977.

2. Smith, 1964; Asad, 1993; Asad, 2001; Boyarin, 2004; Nongbri, 2013.

3. Naerebout, 2014.

4. CNRS, 1966; Birley, 1997; Boatwright, 1987; Boatwright, 2000. For an evocative account of the empire in the reign of Hadrian see Danziger y Purcell, 2005. 
ious religious traditions and centres provides a basis for rethinking how we understand the religious role of Roman emperors in general.

\section{HAdrian's Religious Activity}

Our evidence for Hadrian's religious activity is late and fragmentary, as is true for all aspects of his reign. Most of our synoptic accounts - the life included in the Historia Augusta and the very short accounts by Aurelius Victor, Eutropius and the Epitome de Caesaribus - were composed in the fourth century AD. Dio's account, composed two generations after Hadrian's death, survives only in the eleventh-century summary produced by the Byzantine monk John Xiphilinus. Fuller accounts once existed. The Historia Augusta refers to Hadrian's own account of his life, apparently apologetic in tone, and also to a life written by Marius Maximus, a contemporary of Dio and a continuator of Suetonius. The extant narratives may be supplemented by mentions in second and third century literature: Hadrian's interest in intellectual life and his travels in the Greek East means that he features in anecdotes related by Gellius, Fronto, Favorinus, Aristides, Pausanias, and Philostratus among others. Finally a number of letters and decrees have survived in epigraphic form. Only a little of this testimony deals with religious matters.

The religious office of the emperor is not a major focus of attention in any of the surviving narratives. Their recurrent themes are the circumstances of Hadrian's accession, how he dealt with the legacy of Trajanic expansion, Hadrian's relations with the senate and senators, his love for Antinous and the latter's mysterious death, and Hadrian's own miserable end. The narratives are not independent of each other, and none were composed under emperors with a vested interest in Hadrian's reputation, but perhaps they represent a common tradition about the reign. The anecdotes, mostly written down earlier than the narratives, present a man of strong passions who had difficulty in restraining them.

In all this material, the lines of the Historia Augusta which head this chapter are the nearest thing we have to an explicit comment on his religious conduct in general. The context is a chapter of the Life which presents an account of his military activity while emperor followed by an account of his equally disciplined behaviour in relation to civil affairs. Hadrian frequently appointed guardians, promoted the wearing of the toga in public, restrained public extravagance, regulated urban traffic sensibly, discouraged early bathing, and gave equestrians as well as senators a role in government. He subsidized deserving senators, took his judicial duties seriously and involved magistrates and other senior senators in decision making. Any reader of Suetonius's Caesars or Pliny's Panegyricus would have recognised the conventional signs 
of a "good emperor", as the role had been elaborated over the previous century and a half. ${ }^{5}$ What sacra peregrina means depends a good deal on the chronological stratum from which the observation comes. If it draws on second-century sources it might refer to one of the many traditions of Egyptian, Jewish, Anatolian, Syrian or Iranian origin popular in Hadrian's lifetime. If it represents later editorializing it might refer to his treatment of Jews and Christians, and might draw a contrast with the favour shown the later by emperors from Constantine on. It might also, or instead, refer to Suetonius' similar comment on Augustus. ${ }^{6}$ What is certain is that the evaluation is in conventional terms positive. Hadrian supported the traditional public cults of the Roman people, and was punctilious in performing his own role as chief pontiff.

There is also some information conveyed about particular religious rituals in which Hadrian participated. On his accession he immediately became Pontifex Maximus and an Arval Brother. He participated conscientiously in these and other priestly roles in the City. ${ }^{7} \mathrm{He}$ sponsored a number of spectacles. On the occasion of his praetorship, probably in $107 \mathrm{AD}$, he was given 4 million HS by Trajan to celebrate games in Rome. ${ }^{8}$ He organized a posthumous triumph for Trajan to mark the victory over the Parthians, and regular Parthian games were established. ${ }^{9}$ He held six days of lavish games on the occasion of his succession, had 1000 beasts in the arena on his birthday and later funded spectacular funeral games for his mother-in-law Matidia. ${ }^{10}$ Trajan, Matidia and Antinous were all consecrated as gods after their deaths and so probably were Trajan's wife Plotina, his sister Marciana and Hadrian's wife Sabina. ${ }^{11}$ Consecrations were initiated by decrees of the senate, but there is no real doubt that they followed the wishes of the emperor of the day. ${ }^{12}$ There were also games to mark his adoption of Aelius Verus Caesar. ${ }^{13}$ Other anecdotes refer to Hadrian attending gladiatorial combats and chariot racing in Rome, a traditional sign of civilitas.

5. Wallace-Hadrill, 1982; Roller, 2001; Noreña, 2011.

6. See Fündling, 2006. Suetonius' Life of Augustus 93 reads: Peregrinarum caerimoniarum sicut veteres ac praeceptas reverentissime coluit, ita ceteras contemptui habuit.

7. Hist. Aug., Hadr. 22, 10; Aurelius Victor (Caes. 14, 1-4), compares him to Numa. For documentation of his priesthoods see Rüpke, 2005: catalogue number 1016.

8. Hist. Aug., Hadr. 3.

9. Hist. Aug., Hadr. 6 for the triumph. Epitome of Dio's Roman History LXIX 2, 3 for the Parthian Games.

10. Hist. Aug., Hadr. 7 for the accession games, 9 for those for Matidia. For the birthday games Hist. Aug., Hadr. 7; Cass. Dio, LXIX 8, 2.

11. Oliver, 1949 and see now McIntyre, 2016.

12. Price, 1987.

13. Hist. Aug., Hadr. 23, 12. 
Hadrian also restored a number of monuments in the city of Rome. ${ }^{14}$ Not all were temples, but many of them were and they included the Pantheon, the Temple of Bona Dea, and the Forum Augusti which included the Temple of Mars Ultor. The range of deities thus honoured, and the emphasis on restoration was highly traditional, a display of Augustan pietas. ${ }^{15}$ Hadrian's main addition to the religious topography of the city was the Temple of Venus and Rome, described as the Temple of the City by the Historia Augusta and by the broadly contemporary Ammianus. ${ }^{16}$ Despite its enormous scale and innovative design, the Temple of Venus fits comfortably in the tradition of imperial building forums and temples around the forum Romanum. Many of Hadrian's projects seem to have begun in the 120 s AD when questions over his succession to Trajan meant he was concerned to establish his legitimacy in the City, but some were not completed until much later. The Temple of Venus and Rome seems to have been dedicated in 121, consecrated in 135 but not completed until 141. Like Trajan, the first emperor from a provincial background, Hadrian seems to have taken great care to perform his religious functions in a highly traditional manner at Rome, and to conform to precedents set by Augustus and other 'good emperors'.

Our knowledge of Hadrian's religious activities in the provinces is more fragmented. Just as in relation to Rome, the narratives do not separate out his religious from his other interventions. Like other Roman travellers before him - Sulla, Antony, Augustus, Germanicus and Trajan spring to mind - Hadrian's exploration of the east included visits to oracles, tombs and other places of ancient ritual. It is no surprise that he visited Delphi, sacrificed on Mount Casius in Syria, rebuilt the tomb of Pompey at Pelusium in Egypt, was initiated into the mysteries at Eleusis. But it would be misleading to characterise Hadrian's travels as a pilgrimage. ${ }^{17}$ Other stopping points seem less obviously religious, such as when he climbed Mount Etna, toured the sites in Egypt or visited Nicopolis and the site of the battle of Actium. Something like a Grand Tour had developed for Roman visitors to the east - admittedly one that only the very richest could afford - and Hadrian seems to have visited most of the major locations.

14. Hist. Aug., Hadr. 19, 9-12: Cum opera ubique infinita fecisset, numquam ipse nisi in Traiani patris templo nomen suum scripsit. Romae instauravit Pantheum, saepta, basilicam Neptuni, sacras aedes plurimas, forum Augusti, lavacrum Agrippae, eaque omnia propriis auctorum nominibus consecravit. Fecit et sui nominis pontem et sepulchrum iuxta Tiberim et aedem Bonae Deae.

15. Boatwright, 1987 on the building programmes.

16. Hist. Aug., Hadr. 19, 12; Ammianus, XVI 10, 14. For the variants on its name see Steinby, 19932000: S.v. VENUS ET ROMA, AEDES, TEMPLUM.

17. For the debates over pilgrimage and ancient Mediterranean religion, Elsner y Rutherford, 2005. 
Some of the sites attracted benefactions and interventions. ${ }^{18}$ The dossier is enormous and very varied. At Athens these included a water supply, an oil law, the foundation for a library, a new civic quarter, as well as help with the construction of the Temple of Olympian Zeus. ${ }^{19}$ Other communities benefited too, in different ways according to their desires and those of Hadrian. As Dio put it:

He assisted the cities, both those that were allies and those that were subjects, with the greatest of generosity. Many of them he had visited himself, more than any other emperor had done, and practically all of them he helped, providing some with water supply, others with harbours, some with grain, others with public works or simply gifts of cash, making different gifts to each of them..$^{20}$

The Historia Augusta puts it even more simply. In almost all the cities he built something and gave games. ${ }^{21}$

This broad conception of imperial euergetism is the context for the help he gave to the oracular sanctuaries at Delphi and Didyma, for his restoration of the oracle at Claros, and for the rebuilding of temples at Baalbek and Palmyra. Our ancient witnesses present these benefactions as comparable to other projects of rebuilding and restoration.

This is also the case if we consider Hadrian as a city founder. The emperor is often criticised for religious insensitivity in establishing Colonia Aelia Capitolina on the site of Jerusalem, sacked a generation before in the Flavian Jewish War. There is no doubt that this foundation did arouse a bitter reaction, but there are Roman contexts in which it seems less controversial. The destruction of ancient cities often made Greeks and Romans feel uncomfortable. To some extent the sacred topography of the Mediterranean world was taken as a given: the removal of cities, as Alexander had done at Thebes and the Romans in 146 at Carthage and Corinth, left a permanent scar. ${ }^{22}$ Those three destructions had been reversed, but the destruction of Jerusalem had not. The opening lines of the fifth book of Tacitus' Histories, written in the reign of Trajan, shows it might be thought of as an analogous case, and Epiphanius, writing in the fourth century, believed Hadrian's intention was to restore the city, not the

18. Boatwright, 2000.

19. Spawforth y Walker, 1985. Interventions that need to be placed in a longer context of relations between emperors and Athenian élites Oliver, 1970; Follet, 1976; Oliver, 1983; Hoff y Rotroff, 1997; Lozano Gómez, 2002; Muñiz Grijalvo, 2005.

20. Cass. Dio, LXIX 5, 2-3 (author's translation).

21. Hist. Aug., Hadr. 19, 2 (trans. Birley): In omnibus paene urbibus et aliquid aedificavit et ludos edidit.

22. Purcell, 1995. 
Temple. ${ }^{23}$ As at Corinth and Carthage the refoundation took an entirely Roman form while making some concessions to previous sacred topography. A veteran colony was laid out with a cardo and a decumanus and at their junction was a forum with a temple of Venus. On what is now the Temple Mount a temple was almost certainly built to Jupiter Capitolinus. ${ }^{24}$ IOM was syncretised with the sky gods of Baalbek, Doliche and other city states, so might have seemed a natural translation of Yahweh. The pool of Bethesda became a sanctuary of Sarapis. The decurions of the colony issued more than 100 bronze coin types over the century or so that followed. ${ }^{25}$ Their reverses often depict imperial relatives, legionary badges like the Boar of the Legio X Fretensis, and common Roman imagery such as the she-wolf with Romulus and Remus and the eagle. Otherwise they show temples with cult statues in them, or simply depict gods, among them Sarapis, Mars, Fortuna/the Tyche of the City, Minerva, Jupiter, the Dioscuri, Salus, Victoria. What Hadrian had established was a working Roman city with Roman roads, Roman temples, Roman magistrates and Roman gods. Antinoopolis in Egypt too was laid out as a complete city, a polis this time rather than a Roman colony, but one equipped with all the cultural, political, social and religious infrastructure such a community required from citizens to temples of the gods.

\section{Policy, Consistency, and Imperial Initiative}

Hadrian is unusual in having left so many traces of his interventions around the empire. Several factors made it possible. He reigned for more than 20 years, much longer than most emperors. Trajan's conquests had probably left the treasuries full even after his own building in Rome and the alimentary schemes he established in Italy. Dio and the Historia Augusta mention various military engagements in the reign of Hadrian - a revolt in Mauretania, the abortive invasion by the Alani, and of course the war with Jews in Judaea and the diaspora. But there is no reason to think the empire was placed under unusual financial strain. Hadrian had the time and money to build, and the inclination to do so. The main beneficiaries of his generosity were the city of Rome and the ancient cities and sanctuaries of the eastern Mediterranean, although he did build and spend elsewhere. Neither he nor his chroniclers seem to have sharply distinguished generosity directed at religious centres from other kinds of benefaction. When his interventions did have religious dimensions they seem traditional,

23. Tac., Hist. 5, 2: Sed quoniam famosae urbis supremum diem tradituri sumus, congruens videtur primordia eius aperire. On Epiphanius' account see Baker, 2012.

24. For some doubts see Eliav, 1997.

25. http://rpc.ashmus.ox.ac.uk/.

ARYS, 16, 2018 [47-61] ISSN 1575-166X 
funding ancient temples in Greece and Syria, carrying out conventional rituals in Rome and masking most of his more innovative building under the always acceptable label of "restoration". Even overseas he went to the same places many other Romans had gone before, to Eleusis, to Troy, to Alexandria.

These actions seem consistent with each other but it is not easy to determine the source of that consistency. Policy seems to be the wrong term. The notion that individual emperors had fixed policies has always seemed a little strange. Why should any ancient monarch bind himself by a series of rigid protocols, given that even today politicians have to adapt to changing events? Habit, inclination, disposition seem better terms. Most ancient narratives, which under the principate often took a biographical form, tried to understand imperial action as an expression of the characters of individual emperors. That perspective is natural from writers living under the emperors and in many cases close to the imperial court. Changes of emperor might make a huge difference to those who surrounded them.

It is equally natural that in the longer term variations between reigns seem less significant. It is common to treat the early empire as a largely stable system, and to explain this as having been produced by a mixture of ideology, habit, path-dependence, economic constraints or governmental instruments that were relatively weak and not very flexible. Individual emperors made less of a difference in this view, constrained as they were by the structures they had inherited. The view of the emperor's role advanced by Fergus Millar in The Emperor in the Roman World was in part a response to histories that seemed to him to over-estimate any given emperor's capacity to change his world. ${ }^{26}$ Millar's emphasis on "petition-and-response" asserted the relative ignorance of emperors and their relative powerlessness, to the extent that their role was often reduced simply to making decisions on questions put to them. ${ }^{27}$ Comparative studies have now made clear that the rulers of other early empires laboured under similar constraints. Rather than energizing and steering their vast domains, many early emperors were 'capstone monarchs', figures whose main function was to stabilize other interests, like those of the army, landowners, urban elites, taxpayers and tenants and so on. ${ }^{28}$ But we do now find ourselves at odds with our witnesses. Reigns like Hadrian's really bring this disparity into focus.

26. Millar, 1977.

27. Millar, 1990.

28. Crone, 1989. 
As early responses to Millar's thesis noted, "petition-and-response" works better as an account of imperial action in some spheres than in others. ${ }^{29}$ Emperors did indeed often have to respond to requests for arbitration, or to petitions for grants of personal or civic status and the like, but they had to take the initiative in areas such as the organization of taxation, or the strategic direction of military operations. ${ }^{30} \mathrm{Re}-$ ligious matters (as we define them) were sometimes brought to emperors' attention by others, and sometimes were the object of imperial initiative. For example 'petition-and-response' does characterise quite well the embassies that came to emperors seeking resolution to disputes over rights of asyla, or over the ownership of border sanctuaries. Tiberius' referral of some of these matters to the senate reveals the Republican origins of "petition-and-response" Yet when it came to the construction of the Isaeum Campestre or the choice of deities honoured in imperial fora, we are clearly dealing with the pro-active initiatives of emperors, whatever advice they may have sought in advance.

Not all emperors were equally constrained in their actions. Not all emperors were equally ignorant of their domains. Some emperors tried harder than others to take the initiative, and to wrest power from their courtiers and escape the constraints they had inherited. ${ }^{31}$

Hadrian was certainly one of those Roman emperors who had more than freedom of action than most. After the early years of his reign his position was relatively secure. The empire he inherited was financially well resourced. Compared to some of his successors he faced no sudden and expensive challenges. Hadrian also arguably knew his empire better than any of his predecessor since Augustus, simply because he had travelled so much of it in his long reign. Comparison with other second-century emperors shows that he might have made other choices, or at least might have had different priorities. He could have continued expansion on the model of Trajan, he could have remained in or near the capital as Pius did, or he could have indulged other interests, perhaps those of a Marcus or a Commodus. He could have spent, or he could have hoarded.

What Hadrian chose to do was to travel and to spend. His dispersal of imperial resource does not seem to have followed a plan that was either narrowly conceived or devised in advance. Many private benefactors had particular areas of interest, athlet-

29. Hopkins 1978; Bleicken, 1982.

30. Campbell, 1984.

31. For a similar argument made in relation to the Ancien Regime in early modern France see Elias, 1979.

ARYS, 16, 2018 [47-61] ISSN 1575-166X 
ics or literary culture, festivals or buildings and so on. The same was true of emperors. ${ }^{32}$ Close reading of some epigraphic memorials alongside some speeches of Dio and some titles of the Digest suggests that tensions often arose between the needs or cities and the interests of potential benefactors. ${ }^{33}$ Those clashes of ego and desire, and struggles for control over gifts, are familiar from modern fund-raising. Imperial benefactors probably did not do much of this negotiation. Hadrian, on the other hand, does seem to have been responsive to local circumstances, aware that some places needed fortifications and others aqueducts, while yet others needed help to restore dilapidated temples.

Caution is called for since our sources are neither close in time to his reign nor very reliable. We have in the end only fragments of his religious activity to consider. Much of our testimony was produced in a Roman empire which, in religious terms at least, was no longer very similar to Hadrian's world. The gaps in our knowledge may be the most serious problem. Even in the city of Rome much remains controversial about his building projects: a vast temple of Sarapis on the Quirinal might or might not be his creation, and his role in shaping the tomb cult of Trajan is debated. ${ }^{34}$ That said, it does seem that Hadrian was in general sensitive to local religious traditions. In Rome and Athens, Baalbek and Palmyra, Claros and Sparta Hadrian spent to restore, repair and glorify rather than replace. Even in Jerusalem his colony was as traditional a Roman colony as was possible in that age, and may have been intended too as an act of restoration. Where we do not have enough information to be certain as to his intents, I suggest the most likely interpretation is the one that has him respond to local circumstances rather than impose a bold new religious programme. ${ }^{35} \mathrm{He}$ was no Akhenaten, no Constantine, no Julian.

Hadrian was not the only benefactor whose religious activity was largely channelled into reinforcing traditional patterns of activity. All benefactors had options, and when they wished could make and realize ambitious plans, whether that meant the script for festivals like the Demostheneia of Oenoanda or the design for the Temple of Venus and Rome. Hadrian's decision to sponsor traditional religion may have been pragmatic in the City of Rome, but it was more of a free choice in the provinces where cities had to be grateful for what they received and could not exercise much pressure on imperial benefactors. The most likely explanation for the choices that

32. Woolf, 1994.

33. Mitchell, 1990; Rogers, 1991; Garnsey, 1991.

34. Taylor, 2004, for the Serapeum. Claridge, 1993, for Hadrian and the Trajanic Forum.

35. The most obvious area to test this proposal is on the debate over the nature of the Panhellenion Spawforth and Walker, 1986; Jones, 1996; Spawforth, 1999. 
Hadrian made is that - like most of the wealthy and powerful of his day - he saw no reason to doubt the efficacy of the traditional cults. Old rituals and ancient oracles had served the emperors and the empire well. Those rituals included the sacra publica of Rome, and also the ancient rituals of Demeter at Eleusis or Sarapis from Egypt. Tradition, in other words, may have been a positive and deliberate choice. Perhaps a willingness to spend on those gods who had been powerful supporters in the past, was a religious policy of a sort. 


\section{BibLIOGRAPHY}

Asad, T. (1993). Genealogies of religion. Discipline and reasons of power in Christianity and Islam. Baltimore and London: Johns Hopkins University Press.

Asad, T. (2001). On reading a modern classic W.C. Smith's The Meaning and End of Religion. History of Religions, 40.3, pp. 205-222.

Baker, R. (2012). Epiphanius, On Weights and Measures \$14: Hadrian’s Journey to the East and the Rebuilding of Jerusalem. Zeitschrift für Papyrologie und Epigrafik, 182, pp. 157-167.

Birley, A.R. (1997). Hadrian. The restless emperor. London and New York: Routledge.

Bleicken, J. (1982). Zum Regierungsstil des römischen Kaisers. Eine Antwort auf Fergus Millar. Sitzungsberichte der Wissenschaftlichen Gesellschaft an der Johann Wolfgang GoetheUniversität Frankfurt am Main, 18.5, pp. 184-215.

Boatwright, M.T. (1987). Hadrian and the City of Rome. Princeton N.J.: Princeton University Press.

Boatwright, M.T. (2000). Hadrian and the Cities of the Roman Empire. Princeton N.J.: Princeton University Press.

Boyarin, D. (2004). The Christian invention of Judaism. The Theodosian empire and the rabbinic refusal of religion. Representations, 85, pp. 21-57.

Bricault, L. and Versluys M.J. (eds.) (2014). Power, Politics, and the Cults of Isis. Proceedings of the Vth International Conference of Isis Studies, Boulogne-sur-Mer, November 27-29, 2008. Leiden and Boston: Brill.

Campbell, B. (1984). The Emperor and the Roman Army 31 BC - AD 235. Oxford: Clarendon Press.

Cannadine, D. and Price, S. (eds.) (1987). Rituals of Royalty. Power and ceremonial in traditional societies. Cambridge: Cambridge University Press.

Claridge, A. (1993). Hadrian's Column of Trajan. Journal of Roman Archaeology, 6, pp. 5-22.

CNRS (ed.) (1966). Les Empereurs Romains d'Espagne. Paris: Éditions du Centre national de la recherche scientifique.

Crone, P. (1989). Pre-industrial Societies. New Perspectives on the Past. Oxford: Basil Blackwell.

Danziger, D. and Purcell, N. (2005). Hadrian's Empire. When Rome ruled the world. London: Hodder \& Stoughton.

Elias, N. (1979). Die höfische Gesellschaft. Untersuchungen zur Soziologie des Königtums und der höfischen Aristokratie mit einer Einleitung: Soziologie und Geschichtswissenschaft. Darmstadt: Luchterhand [The Court Society. Oxford: Blackwell 1983].

Eliav, Y.Z. (1997). Hadrian's Actions in the Jerusalem Temple Mount According to Cassius Dio and Xiphilini Manus. Jewish Studies Quarterly, 44.2, 125-144.

Elsner, J. and Rutherford, I. (eds.) (2005). Pilgrimage in Graeco-Roman and early Christian Antiquity. Seeing the gods. Oxford: Oxford University Press.

Follet, S. (1976). Athènes au IIe et au IIIe siècle : études chronologiques et prosopographique. Paris: Les Belles Lettres. 
Fündling, J. (2006). Kommentar zur Historia Augusta. Antiquitas. Bonn: Dr Rudolph Habelt GMBH.

Garnsey, P. (1991). Review Article. The Generosity of Veyne. Journal of Roman Studies, 81, pp. 164-168.

Hoff, M.C. and Rotroff, S.I. (eds.) (1997). The Romanization of Athens. Oxbow Monograph XCIV. Oxford: Oxbow Books.

Hopkins, K. (1978). Rules of Evidence. Journal of Roman Studies, 68, pp. 178-186.

Innes, D., Hine, H. and Pelling, Ch. (1995). Ethics and Rhetoric. Classical essays for Donald Russell on his seventy-fifth birthday. Oxford: Clarendon Press.

Jones, C.P. (1996). The Panhellenion. Chiron, 26, pp. 29-56.

Lozano Gómez, F. (2002). La religión del poder. El culto imperial en Atenas en época de Augusto $y$ los emperadores Julio-Claudios. BAR International Series. Oxford: Archaeopress.

Mcintyre, G. (2016). A family of gods. The worship of the imperial family in the Latin West. Ann Arbor MI: University of Michigan Press.

Millar, F. (1977). The Emperor in the Roman World (31 BC-AD 337). London: Duckworth.

Millar, F. (1990). L'empereur romain comme décideur. In Nicolet, 1990, pp. 207-220.

Mitchell, St. (1990). Festivals, games and civic life in Roman Asia Minor. Journal of Roman Studies, 80, pp. 183-193.

Muñiz Grijalvo, E. (2005). Elites and religious change in Roman Athens. Numen, 52. 2, pp. 255-282.

Naerebout, Fr.G. (2014). Cuius regio, eius religio? Rulers and Religious Change in Greco-Roman Egypt. In Bricault and Versluys, 2014, pp. 36-61.

Nicolet, Cl. (ed.) (1990). Du pouvoir dans l'antiquité. Mots et réalités. Geneva: Droz.

Nongbri, B. (2013). Before Religion. A history of a modern concept. New Haven and London: Yale University Press.

Noreña, C. (2011). Imperial ideals in the Roman West. Representation, circulation, power. Cambridge: Cambridge University Press.

Oliver, J.H. (1949). The Divi of the Hadrianic Period. Harvard Theological Review, 42.1, pp. 35-50.

Oliver, J.H. (1970). Marcus Aurelius. Aspects of civic and cultural policy in the East. Hesperia Supplements. Princeton N.J: ASCSA.

Oliver, J.H. (1983). The Civic Tradition and Roman Athens. Baltimore MA: Johns Hopkins University Press.

Price, S. (1987). From noble funerals to divine cult: the consecration of Roman emperors. In Cannadine and Price, 1987, pp. 56-105.

Purcell, N. (1995). On the Sacking of Carthage and Corinth. In Innes, Hine and Pelling, 1995, pp. 133-148.

Rogers, G.M. (1991). Demosthenes of Oenoanda and Models of Euergetism. Journal of Roman Studies, 81, pp. 91-100.

Roller, M.B. (2001). Constructing Autocracy. Aristocrats and emperors in Julio-Claudian Rome. Princeton N.J.: Princeton University Press. 
Rüpke, J. (2005). Fasti Sacerdotum. Die Mitglieder der Priesterschaften und das sakrale Funktionspersonal römischer, griechischer und jüdisch-christlicher Kulte in der Stadt Rom von 300 v. Chr. Bis 499 n. Chr., 3 vols. Potsdamer Altertumswissenschaftlicher Beiträge. Stuttgart: Franz Steiner Verlag.

Smith, W.C. (1964). The Meaning and End of Religion. A new approach to the religious traditions of mankind. Mentor Books. New York: New American Library.

Spawforth, A.J.S. (1999). The Panhellenion Again. Chiron, 29, pp. 339-352.

Spawforth, A.J.S. and Walker, S. (1985). The World of the Panhellenion. I. Athens and Eleusis. Journal of Roman Studies, 75, pp. 78-104.

Spawforth, A.J.S. and Walker, S. (1986). The World of the Panhellenion. II. Three Dorian Cities. Journal of Roman Studies, 76, pp. 88-105.

Steinby, E.M. (ed.) (1993-2000). Lexicon Topographicum Urbis Romae, 6 vols. Rome: Edizioni Quasar.

Taylor, R. (2004). Hadrian's Serapeum in Rome. American Journal of Archaeology, 108.2, pp. 223-266.

Wallace-Hadrill, A. (1982). Civilis princeps. Between citizen and king. Journal of Roman Studies, 72 , pp. 32-48.

Woolf, G. (1994). Becoming Roman, Staying Greek: Culture, Identity and the Civilizing Process in the Roman East. Proceedings of the Cambridge Philological Society, 40, pp. 116143. 